\title{
MANAGEMENT OF ISLAMIC EDUCATION ON INDONESIAN LANGUAGE LEARNING FOR FOREIGN SPEAKER PROGRAM
}

\author{
Siti Isnaniah \\ IAIN Surakarta \\ Jl. Pandawa Pucangan Kartasura Sukoharjo Jawa Tengah, Indonesia, 57168 \\ Email: sisnaniah7@gmail.com
}

\section{Fauzan Mustofa}

Universitas Liga Arab Mesir

Masaken Atlas, Gedung 7, Flat 16, Musalas, Nasr City, Kairo, Mesir

Email: nazuafafotsum@gmail.com

Received: 05, 2020. Accepted: 12, 2020. Published: 12, 2020

\begin{abstract}
This study aims to compare the management of Islamic education for the BIPA (Bahasa Indonesia Penutur Asing/Indonesian Language Learning for Foreign Speaker) program at PTKI institutions in Indonesia and Al-Azhar University in Egypt from the aspects of the curriculum, institutions, teachers, students, and evaluation. This research used descriptive analytic method with a qualitative approach. In-depth interviews, content analysis, and observation were applied to collect the data. Data were analysed using the interactive model of Miles \& Huberman and comparative analysis. The result of the research showed that BIPA management conducted by PTKI institutions and Al-Azhar university, Egypt in terms of institution, curriculum, language teachers, language learners, evaluation have applied islamic perspective (Aqeeda and Sharia) and Islamic values which are compatible with the regulation set by Direktur Jenderal Pendidikan Islam (Directorate General for Islamic Education) Number 6244 Year 2019. Referring to this regulation, both BIPA program at PTKI institutions and Al-azhar university are considered ready and successful.
\end{abstract}

Keywords: Curriculum, Indonesian Language Learning, Islamic Educational Management

\section{ABSTRAK}

Penelitian ini bertujuan membandingkan pengelolaan pendidikan Islam untuk program BIPA di PTKI Indonesia dan Universitas Al-Az̧har di Mesir dari aspek kurikulum, institusi, pengajar, mahasiswa, dan evaluasi. Penelitian ini menggunakan metode deskriptif analitik dengan pendekatan kualitatif. Teknik pengumpulan data dilakukan dengan wawancara mendalam, analisis isi, dan observasi. Data dianalisis menggunakan model interaktif Miles \& Huberman dan analisis komparatif. Hasil penelitian menunjukkan babwa manajemen BIPA di PTKI dan Universitas AlAžbar Mesir dari kelembagaan, kurikulum, pengajar, pemelajar, evaluasi diajarkan dengan menerapkan wawasan keislaman (akidah, syariah) dan nilai keislaman (akblak) yang sesuai dengan Regulasi Direktur Jenderal Pendidikan Islam Nomor 6244 Tabun 2019. Hal ini menunjukkan babwa manajemen pendidikan Islam pada BIPA di Universitas Al-Azhar Mesir dan di PTKI dikategorikan siap dan berbasil.

Kata Kunci: Kurikulum, Manajemen Pendidikan Islam, Pembelajaran Bahasa Indonesia 


\section{INTRODUCTION}

Indonesian has become an international language that is widely used by the international community at home and abroad. This has prompted the preparation of guidelines for the use of Indonesian for foreigners, so that the government has regulated the use of Indonesian based on Law No. 24 of 2009. Article 29 paragraph (1) of the law states that Indonesian must be used as the language of instruction in national education. Based on this law, both Indonesian citizens and foreign nationals are required to use the Indonesian language when participating in learning programs in Indonesia. This law was also reviewed to encourage the establishment of the BIPA (Babasa Indonesia Penutur Asing/Indonesian Language for Foreign Speakers) Program (Kurniasih \& Isnaniah, 2019)

The BIPA program is deliberately designed in Indonesian language learning activities whose subjects are foreign learners, so that it focuses on the learners. BIPA learning is oriented towards mastering Indonesian language skills for foreigners (Kusmiatun, 2016). BIPA students are foreign citizens who do not yet understand the basics and grammar of Indonesian but are interested in learning the language (Suyitno, 2008). The main objective of foreign students studying BIPA is to fluently speak Indonesian and get to know Indonesian culture more deeply. Fluency mastery in Indonesian language is needed by BIPA students because they; (1) generally take programs about Indonesia at their home universities; (2) will conduct some research in Indonesia; (3) will work in Indonesia; (4) will research problems regarding the Indonesian language; and (5) plan to stay in Indonesia for a long time. Other studies conducted by (Isnaniah \& Islahuddin, 2020; Saddhono, 2012) explain that students who speak foreign languages are required to master Indonesian as their second language so that it is easier to communicate, especially in the learning process and completing academic assignments on campus.

BIPA program should have well-prepared curriculum. According to (Lestyarini, 2012), the development of curriculum for teaching Indonesian for foreign speakers must be endeavored to comply with international standards and be conducive to its implementation. This is because the position of the Indonesian language in the present era is increasingly important in the international arena. According to (Rafiek, 2014), the opportunity for Indonesian to be developed into an international language is wide open because it has been taught at several universities abroad, such as Russia, Japan, the United States, Australia, China and Germany Soegihartono (2012) emphasized that BIPA program has spread throughout the continent organized by 179 institutions. These institutions include universities, the Indonesian Embassy (KBRI), cultural centers, Indonesian schools abroad and other course institutions. According to Haryati et al., (2019), in one of the presentations at the plenary session of the IX Indonesian Language Congress, it was revealed that currently there are 45 countries that teach Indonesian, such as Australia, America, Canada, Vietnam, and many other countries. In Australia, for example, Indonesian is the fourth most popular language. Kurniasih \& Isnaniah (2019) explain that BIPA activities are held in tertiary institutions in the form of opening study programs, such as the BIPA master program at the Indonesian Education University.

In Indonesian PTKI (Perguruan Tinggi Keagamaan Islam/Islamic Higher Education Institutions), there is no BIPA study program because its activities are in the form of activities outside the study program. For some PTKI institutions, BIPA program is institutionally under the Vice Rector for Student Affairs and Cooperation. Other institutions, BIPA program is administered under the Language Development Center. Some institutions even provide BIPA program in the form of matriculation. Overseas, BIPA program has been administered in several countries. In Egypt, the program has been properly administered (Kurniasih \& Isnaniah, 2019) 
BIPA in the context of Islamic education at PTKI institutions needs to be managed well to achieve good quality program. Management of Islamic education according to (Muhaimin \& Prabowo, 2012) is a process of using resources effectively to achieve goals that are imbued with Islamic values. Islamic education management includes: input, curriculum, instructors, infrastructure, funds, institutions, environment, and output (Supriyanto, 2004). Islamic education management also requires some aspects like instructional and conditional to perform well. The instructional aspect consists of learning objectives, teaching materials, media, methods, class management, students, and evaluation. Meanwhile, the conditional aspect consists of conditioning the readiness of students' needs, exposure and literacy efforts in real language situations, conditioning the learning atmosphere, and independent training (Liliana, 2017). BIPA learning which is influenced by the instructional and conditional aspects of its students often faces challenging conditions in seeking information resulting from the transformation of culture, language, and education (Binsahi et al., 2020). This reality requires good educational management.

Philospohically speaking, Islamic education management can be seen from from its ontology, epistemology, and axiology. Its Ontology is related to Islamic education institutions and learning resources. Its epistemology as a method is related to management, processes, and ways of getting around. Its axiology is related to the achievement of the goals of Islamic education. In addition, axiology is related to the effectiveness of management of Islamic education, while efficiency focuses on epistemology (Qomar, 2007).

PTKI institutions needs to improve its quality to achieve international standard. In line with this, (Thoyib, 2008) conducted research on the management of Islamic education at PTKI. The finding explains that improving the quality of PTKI can be done through institutional internationalization. This can be done with the support of a strategy for developing the quality of the Islamic higher education system which includes three things; (1) international scale orientation, (2) good academic atmosphere support, and (3) humanistic sense of diversity must be the primary support for PTKI in efforts to internationalize education.

There are several studies concerning BIPA. In terms of its implementation, (Quinones \& Marissa, 2020) conducted a research on the impact BIPA on the empowerment of students' macro skills at the Polytechnic University of the Philippines. Dealing with instructional media, Putra (2020) reported the use of instructional media in the management of BIPA learning. Jannah \& Gusti Yanti (2020) revealed that the methods of imagert on BIPA learning through the Imagery and tourism method. Another research by Zulfahmi (2016) focused on BIPA learning related to the tutorial learning model. Isnaniah \& Islahuddin (2020) conducted research at PTKI institutions and BIPA program in Thailand. The results of the research show that BIPA program at PTKI and BIPA program in Thailand have collaborated in improving the management of the BIPA program. The collaboation includes management of curriculum, institutions, teachers, students, facilities and infrastructure, and so on. There is little information on Islamic education management for BIPA program in Egypt.

There is a need to conduct study on management of Islamic education through the BIPA program Egypt. The country has so far been a partnering country that has contributed to the development of Islamic education, especially represented by Al-Azhar University. According to Sangidu, et al. (2013) describes the condition and development of education in Egypt. Along with the rapid development of Egyptian students learning Indonesian as foreign language speakers, the BIPA program and its management are important to investigate. This article was aimed at comparing Islamic education management through the BIPA program at PTKI institutions in Indonesia and in Egypt. The comparative study includes curriculum, instructors, learners, and program evaluation. 


\section{METHOD}

This study used a descriptive-analytic method with a qualitative approach. Participants took a part in this study included officials from BIPA both in Indonesia and in Egypt. They comprised of teachers, managers, Atdikbud of the Indonesian Embassy in Egypt, International Office of PTKI institution. The data were collected using in-depth interviews, observation and documentation. Content analysis was applied. Data were analyzed using the interactive model of Miles \& Huberman and comparative analysis. Miles \& Huberman's interactive model uses several steps namely data collection in the field, data display, data reduction, and conclusion. If the study has not reached the conclusion, the researcher, according to the cycle technique, returns to the field to collect data and proceed to data analysis to answer research question.

\section{RESULTS AND DISCUSSION}

This study has several findings. The findings includes Overview of BIPA program, Existence of BIPA program at PTKIS institutions in Indonesia and Egypt, BIPA Program Curriculum, BIPA teachers and BIPA Evaluation of program. Those findings will be described and then discussed with the relevant literature.

The progress of the Indonesian nation in the era of globalization and its role in the association between nations has positioned Indonesian as one of the most important languages in the world. This, among others, can be seen from the role of the Indonesian nation in resolving various political conflicts in various countries or Indonesia's geographical position in strategic maritime routes. This reality causes many foreigners to be interested in studying Indonesian for various purposes (Adryansyah, 2012). Until now, Indonesian has been taught to foreigners in various institutions, both at home and abroad. Domestically, it is recorded that no less than 45 institutions have carried out BIPA program for foreigners, both at universities and in course institutions. Abroad, BIPA program has been carried out by around 36 countries in the world with no less than 130 institutions, consisting of universities, foreign cultural centers, the Indonesian Embassy, and course institutions. Various countries that host BIPA consist of countries with English and Arabic backgrounds (Haryati et al., 2019). Countries with an Arabic background are the most common background for a country holding BIPA program. One of them is Egypt. BIPA program in Egypt has come a long way since its inception in 1987.

Various regulations have been established by the government in order to strengthen the function of the Indonesian language in the country and internationalize the Indonesian language. The legal basis for strengthening the function of the Indonesian language in the country, namely Law number 24 of 2009 concerning the flag, language and symbols of the state, as well as the national anthem (Hertiki, 2018). Presidential Decree number 20 of 2018 concerning the use of foreign workers (article 26); Presidential Decree number 63 of 2019 concerning the use of the Indonesian language (articles 2-42); Minister of Manpower Regulation number 10 of 2018 concerning procedures for the use of foreign workers (article 31).

The government has also provided several regulations to support BIPA program. The legal basis for internationalizing the Indonesian language is Law number 24 of 2009 concerning the flag, language and symbol of the state, as well as the national anthem (article 44); Government Regulation number 57 of 2014 concerning the development, guidance and protection of language and literature, as well as the improvement of the function of the Indonesian language (article 31); Permendikbud number 42 of 2018 concerning national policies on language and literature (article 19); Regulation of the Minister of Religion of the Republic of Indonesia Number 38 of 2015 concerning Scholarships and Darmasiswa for 
Foreign Students in Indonesia (articles 8-9); Decree of the Director General of Islamic Education number 6244 of 2019 concerning the national standard of Indonesian language teaching training for foreign speakers (BIPA) at PTKI institutions. This regulation has strengthened the function of the Indonesian language at home and abroad, especially the Regulation of the Director General of Islamic Education number 6244 of 2019 has further strengthened the existence of BIPA in PTKI. Islamic education in this context requires good management in learning, including the curriculum (Rahman et al., 2019). In relation with BIPA program, the higher education institutions should manage the program well to serve the need of foreign students learning Indonesian language (Dewi et al., 2019)

\section{Existence of BIPA Program at PTKI Institutions in Indonesia and Egypt}

BIPA program at PTKI institutions is growing rapidly in line with the increasing number of foreign students coming and studying at PTKI. It is reinforced by the SNP for BIPA program at PTKI institution. The regulation on BIPA is issued by the Directorate of Higher Education for Islamic Religion, the Directorate General of Islamic Education at the Ministry of Religion of the Republic of Indonesia in 2020, which includes the Decree of the Director General of Islamic Education number 6244 of 2019 regarding National Standards for BIPA at PTKI. This confirms that the PTKI institutions in the Ministry of Religion of the Republic of Indonesia has BIPA teaching standards that need to be implemented in all BIPA PTKI institutions. BIPA programs at those institutions so far have been running according to their respective standards.

The SNP for BIPA at PTKI institutions strengthens the previous juridical foundation, Permendikbud No.27 of 2017 concerning Competency Standards for Course Graduates and Training in the Field of Tourism Guidance Skills, Park Maintenance, Health Workers, Construction Carpentry, Brick Installation, Designers, Pipe Installation, Heavy Equipment Mechanics, Language Indonesia for Foreign Speakers, Making Batik with Environmentally Friendly Dyes, Making Batik Night, Making Batik with Synthetic Dyes, Making Writing Canting Tools, and Making Canting Stamp.

The Regulation of the Minister of Religion of the Republic of Indonesia Number 38 of 2015 concerns Scholarships and Darmasiswa for Foreign Students in Indonesia. It sets the procedures to follow by international students seeking for Indonesian scholarship. They have to be able to communicate well using Indonesia after participating in BIPA program. The renewal of the juridical foundation confirms several things. In Permendikbud Number 27 of 2017 there is no Islamic insight and values to carry out in BIPA program. In regulation of SNP for BIPA at PTKI institutions 2020, Islamic insights and values should be promoted in BIPA program. And the substance is more complete than PMA Number 38 of 2015 which is only regulates the obligations of foreign students to study Indonesian. SNP BIPA PTKI 2020 is equipped with graduate competency standards, learning process standards, lecturers and education staff standards, and learning assessment standards.

Based on the field observations, this study found that not all BIPA programs at PTKI institutions have complied with the 2020 SNP for BIPA at PTKI institutions. This happened because the regulation has only just been ratified and issued. Therefore, the regulation should be socialized to all stakeholders of PTKI institutions administering BIPA program. The condition of BIPA program at PTKI instutions vary between the organizing universities, as can be seen in table 1 . 
Tabel 1. Mapping of BIPA Program at PTKI Institutions

\begin{tabular}{|c|c|c|c|c|c|}
\hline No & PTKI & BIPA Status & $\begin{array}{l}\text { Number of } \\
\text { Foreign } \\
\text { Students }\end{array}$ & $\begin{array}{l}\text { Letter of } \\
\text { Cooperation } \\
\text { with PPSDK }\end{array}$ & $\begin{array}{c}\text { Year } \\
\text { Established }\end{array}$ \\
\hline 1. & $\begin{array}{l}\text { IAIN } \\
\text { Tulungagung }\end{array}$ & $\begin{array}{l}\text { Doesn't have BIPA program. } \\
\text { BIPA activities are included in } \\
\text { the Indonesian Education } \\
\text { Department }\end{array}$ & 180 & Not available & - \\
\hline 2. & $\begin{array}{l}\text { UIN } \\
\text { Jakarta }\end{array}$ & $\begin{array}{l}\text { Program run by the language } \\
\text { Centre Unit }\end{array}$ & 131 & available & 2015 \\
\hline 3. & $\begin{array}{l}\text { UIN } \\
\text { Malang }\end{array}$ & $\begin{array}{l}\text { Program run by the language } \\
\text { Centre Unit }\end{array}$ & 100 & available & - \\
\hline 4. & $\begin{array}{l}\text { UIN } \\
\text { Yogyakarta }\end{array}$ & $\begin{array}{l}\text { Doesn't have BIPA program. } \\
\text { BIPA activities run by } \\
\text { Language Centre program }\end{array}$ & 40 & Not available & - \\
\hline 5. & $\begin{array}{l}\text { IAIN } \\
\text { Surakarta }\end{array}$ & $\begin{array}{l}\text { Under the responsibility of } \\
\text { Vice Rector for International } \\
\text { cooperation }\end{array}$ & 32 & available & 2017 \\
\hline
\end{tabular}

Based on table 1, it can be seen that PTKI institutions that are in the good condition and ready to implement the BIPA program include IAIN Surakarta and UIN Jakarta. Both universities have study program for Indonesian Language. They have also supporting language teacher and staff to run BIPA program. The teaching staff at the two institutions has an educational background in Indonesian language education or Indonesian literature. At UIN Jakarta some staff have background in French Literature. Meanwhile, at UIN Malang the BIPA program was not implemented by the Tadris study program or Indonesian Literature. Not all of the teaching staff at BIPA UIN Malang have Indonesian language backgrounds, but some have Arabic and English backgrounds. Although IAIN Tulungagung already has the largest number of foreign students, it does not yet have a BIPA institution. This happens because it has not been supported by the leadership of the institution.

Based on the interview, this study found that the condition of that BIPA in PTKI varies. There are universities that already have BIPA institutions with complete and capable teaching staff, and even have special study programs (tadris study programs). Some of them only have a large number of students, but do not have BIPA institutions because they are not supported by higher education leadership policies. Alternatively, the BIPA learning is included in the matriculation course (Ulfiana, personal communication, December 3, 2019).

In Egypt, the BIPA program was established by the Indonesian Embassy in PUSKIN (pusat Kebudayaan Indonesia/Center for Indonesian Culture and Information. PUSKIN is an institution that aims to promote Indonesian language and culture to foreigners. Since it was first officially established in 1987, PUSKIN has been carrying out various activities, such as introducing and teaching Indonesian language and Indonesian culture. Initially PUSKIN activities focused on teaching Indonesian and were not widely known by the Egyptian community. However, in its development, PUSKIN has received attention from Egyptian people with various backgrounds. In 2009, PUSKIN's performance achieved better. Information about PUSKIN was initially only by word of mouth, then PUSKIN was promoted through advertisements in several newspapers in Egypt. After the promotion was done, more than 300 people have registered to learn Indonesian. However, due to limited classrooms, PUSKIN could not accommodate all applicants, so a selection test was carried out according to the available space capacity. 
PUSKIN has seen a steady increase in the number of Indonesian language learners. It opens selective and professional registrations of Indonesian language teacher candidates. The learning and administrative systems are restructured for better condition in serving the students. In 2009, a team of Indonesian authors was formed under the guidance of Prof. Dr. Sangidu. The team consisting of PUSKIN teachers successfully completed 5 volumes of books to serve as learning material for BIPA program in Egypt.

KBRI (Kedutaan Besar Republik Indonesia/The Embassy of the Republic of Indonesia in Cairo has three locations for teaching Indonesian or BIPA program to the Egyptian community, namely: (1) PUSKIN which is located at 63 Musaddak st. Dokki, Giza, Cairo, (2) PSI (Pusat Studi Indonesia/Center for Indonesian Studies) at Canal Suez Ismailiyah University, and (3) Al-Azhar University, Faculty of Languages and Men's Translation, Nasr City, Cairo. As a continuation of the BIPA program in Egypt, the Indonesian Embassy has prepared BIPA course classes at Cairo University, Ain Syams University, and Banha University in expanding the Indonesian language teaching program in Egypt (Sangidu, 2019). PUSKIN is institutionally under the auspices of the Education and Cultural Attache of the Indonesian Embassy in Cairo. The success of promoting Indonesian language and culture in Egypt became clearer when Cairo's Al-Azhar University welcomed the opening of a BIPA learning center in early 2017.

Al-Azhar University since its foundation (319-365 H/931-975 AD) during the fourth caliph of the Fathimiyah dynasty has always been open to all students from all over the world. In 1965, based on the Decree of the Chairman of the Council of Ministers Number 122 of 1965, the University opened a Language and Translation Faculty with a major in English and French. Then it grew and developed into twelve departments. At the end of 2016, the Language and Translation Faculty expanded by making Indonesian a part of the academic service program at the faculty.

Based on the interview, it is known that BIPA is carried out in collaboration between the Language and Translation Faculty and the Indonesian Embassy in Cairo and the learning process has started since the end of December 2016 academic year. This collaboration is one of the missions of the Indonesian Embassy in Cairo in promote Indonesian to Egyptian society. BIPA program at Al-Azhar University is institutionally under the auspices of the Language and Translation Faculty and its management is technically still under the control of the PUSKIN of the Indonesian Embassy in Cairo. Technically, BIPA program Al-Azhar University is managed by a coordinator who is assisted by local teachers and teaching delegates from PPSDK (Abdurrahim, personal communication, December 5, 2019).

\section{BIPA Program Curriculum}

The curriculum is a set of plans and regulations regarding the objectives, content, learning materials, and methods used as guidelines for implementing learning activities to achieve certain goals (RI Law Number 20 of 2003 concerning the National Education System). The ideal curriculum requires students to think critically because that is the most important thing in learning (Cintamulya, 2019). In Indonesia, BIPA program curriculum used by PTKI institutions contains a formal curriculum and a hidden curriculum. The formal curriculum is guided by the CEFR (Common European Framework of References for Languages), Permendikbud Number 27 of 2017 concerning SKL (Standar Kompetensi Lulusan/Graduate competence standard) for BIPA program, and Decree of the Director General of Islamic Education number 6244 of 2019 concerning the national standard of Indonesian language teaching training for foreign speakers (BIPA) PTKI which contains graduate competency standards, learning process standards, lecturers and education staff standards, and learning assessment standards. 
BIPA program at PTKI institutions in Indonesia also applied hidden curriculum. This type of curriculum covers structural (in-door and out-door activities) and cultural aspects that influence learning situation for BIPA students. In its broadest sense, It includes norms, work ethic, roles and responsibilities, social relations, rituals and worship celebrations, tolerance, cooperation, competition, teacher expectations of students, and discipline. Hidden curriculum is promoted in BIPA program and it is geared more towards culture. BIPA program at PTKI institutions in this context creates a good culture for students by applying Islamic insights (akidah and sharia) and Islamic values (morals), such as the culture of greeting at the beginning and end of learning; tadarus Al-Qur'an; pray in congregation; introduction to Indonesian culture that can be linked to Islam such as Bedhaya dance, Srimpi dance, gamelan, batik, shadow puppets, celebrations in Surakarta: Kirab Pusaka 1 Suro, Sekaten, Grebeg Sudiro, and others; intercultural communication that is still guided by Islamic morals.

In Egypt, the BIPA program at Al-Azhar University also uses a formal curriculum and a hidden curriculum. The curriculum used in BIPA program at Al-Azhar University refers to the curriculum prepared by the PPSDK. The BIPA students at Al-Azhar University are all Muslim. The learner level is divided into 7 mastery levels. Level I is for basic beginners, level II is for advanced beginners, level III is for basic intermediate, level IV for is for intermediate advanced, and so on. The syllabus used refers to the curriculum with some adjustments which is considered important to implement. Teaching materials delivered at BIPA program at PUSKIN and Al-Azhar University feature materials which are compiled by the PUSKIN team and published by the Education and Cultural Attache of the Indonesian Embassy in Cairo. The teaching materials used include Book 1, Book 3, and Book 5 "Smart in Indonesian Language" in the second edition of 2017 published by the Indonesian Embassy in Cairo's Atdikbud as the main teaching material; The book "Sababatku Indonesia" published by PPSDK as supporting/additional teaching material; and additional teaching materials that are independently made by the teacher as supporting teaching materials. At BIPA Al-Azhar University, learning lasts for 90 minutes, 2 meetings a week and runs for 3 months.

In Egypt, the hidden curriculum applied in BIPA program at Al-Azhar University leads to various activities outside the classroom that require language skills (listening, reading, speaking, and writing) to perform by the students. Other materials relate to breaking the fastb(shaum) together, introduction to Eid celebrations, introduction of Islamic terms in Indonesian with Indonesian culture, cooking, performing Islamic arts and languages, and Islamic competitions in Indonesian. Hidden curriculum activities carried out for BIPA program include speech competitions (Figure 1), introduction of terms in Indonesian (Figure 2), Hijri New Year Greetings to Al-Azhar BIPA Students (Figure 3), and Idul Fitri greetings to BIPA Al-Azhar Students (Figure 4).

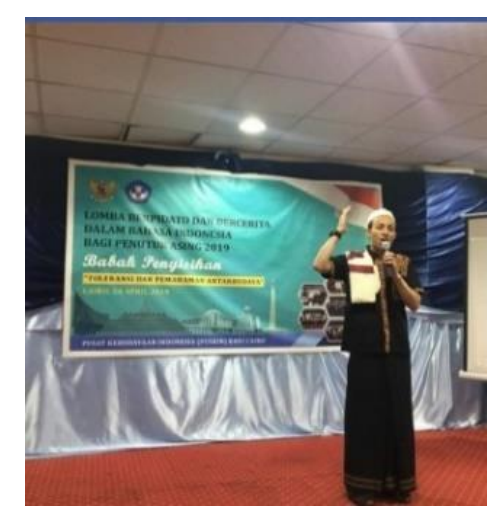

Figure 1. Speech Competition

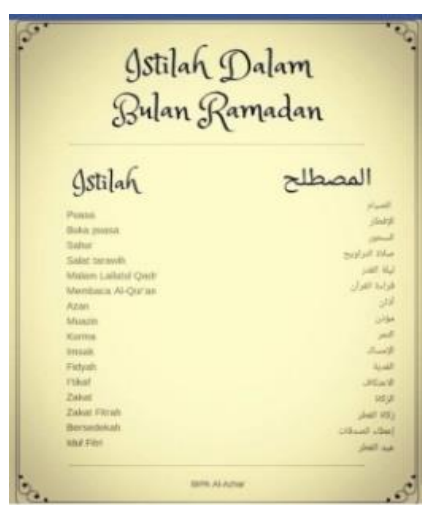

Figure 2. Terms Introduction 
Figure 1 describes the hidden curriculum activities by BIPA students at Al-Azhar University to practice Indonesian language speaking skill through speech activities. Public speaking provide more chances for language learner for demonstrating their speaking skill. Figure 2 describes the introduction of Islamic cultural terms in Indonesia taught to BIPA students in Egypt. The terms used are related to Islam because most Al-Azhar students are Muslims so they know Indonesian culture in an Islamic context. These activities can foster a sense of love from the international community for Indonesian culture.

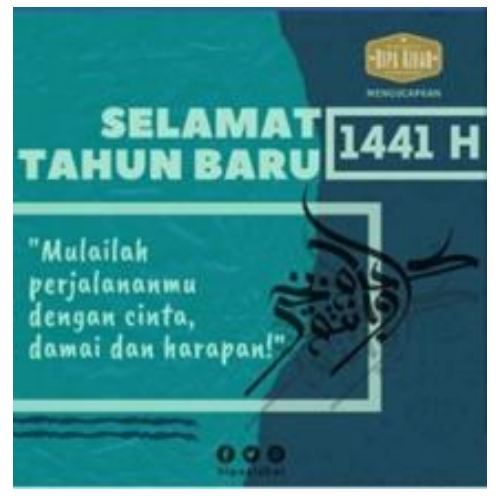

Figure 3. Expression to Celebrate Hijriyah New Year

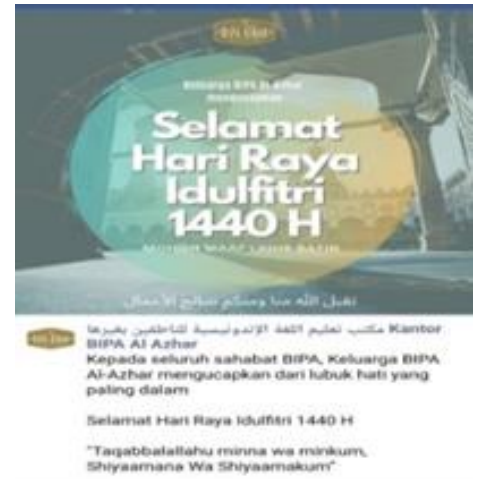

Figure 4. Expression to Celebrate Idul Fitri

Figure 3 describes the activities of BIPA Al-Azhar students so that they are skilled in uttering the utterances of historical days in Islam, such as the Hijri New Year greeting. Indonesians used to express these things with motivational words and prayers of kindness to others. Figure 4 describes the activities of BIPA Al-Azhar students so that they are equipped with the ability to express the utterances of historical days in Islam in the form of greeting Eid al-Fitr.

Beside these activities, other activities are also known in BIPA learning at Al-Azhar University. First, mujamalah (lip service) shows the expression of things that are not serious. These pleasantries are common in everyday life of Indonesian. For example, Indonesian usually ask about the news, and praise each others. The phrase small talk is culturally normal in every country. Egyptian society has a culture of exaggerated courtesy. They start a conversation on the phone, for example, make small talk for almost two minutes, even though the main purpose of the conversation is no more than 10 seconds. Another case is that when an Indonesian goes to Egypt and buys goods or buys something else, when he wants to pay the seller refuses the fee by saying "kholi", "free". The phrase is just lip service. We recommend that someone "jazakallah" and still have to pay. The lip service phrase is found in BIPA learning activities about "the culture of small talk". The material is deliberately published because there are cultural differences between Indonesia and Egypt, because Indonesian people do not make much small talk except under certain conditions.

Second, a culture of excessive praise. The Egyptians have a tradition of praising as part of the miracle. The Egyptian custom when meeting foreigners, they ask how they are and where they come from. If someone answers: "I am from Indonesia", they immediately say "ahsan an-nas" (the best human being), trying to express the praise for the interlocutor. Indonesian people, although in Egypt are well-known and highly civilized, they also say the same expressions to other people from other countries like Russians, Malaysians, Turks or others. This habit can be considered good If it is related to educational teaching activitie. The effort to provide habituation of expressing praise in a particular conversation is very good for 
language learner. This is intended to motivate them to be enthusiastic in learning Indonesian and to familiarize the relationship between lecturers and students.

Third, attendance list in Egypt. Undergraduate students generally are not required to attend learning activities or to attend class (campus). They are required to attend class only to take exams on campus. Therefore, each lecturer does not have an attendance list for the students in a particular subject. Unlike campus activities in Egypt, BIPA program in Egypt requires students to attend the class and participate in learning activities. BIPA has set the requirement to meet by language learner in terms of class presence. Students should attend class at least $75 \%$ of the total study hours. Given this regulation, students should attend learning activities at PUSKIN for at least $75 \%$. This rule is very effective in reducing student absenteeism in learning activities. After the lesson is over, each student tries to make sure that the teacher/lecturer records their attendance in the attendance list. However, these rules need to be well understood to avoid students' culture shock so that teaching and learning activity continues to run smoothly as intended. A cultural approach in accordance with the objectives in the hidden curriculum can improve academic abilities and improve social skills between teachers and students so that they respect each other (Syukur, personal communication, December 6, 2019).

\section{BIPA Teachers}

In Indonesia, at PTKI institutions context, most of the teachers for BIPA have a background in Indonesian Education/Literature. At IAIN Surakarta, the BIPA teachers come from the TBI (Tadris Bahasa Indonesia/Indonesian Language Study Program. However, other PTKIs institutions have diverse background for their BIPA teachers. UIN Malang has the teaching staff with Arabic educational background and UIN Jakarta has the teaching staff with a French Literary background. Likewise, UIN Yogyakarta has the teacher with background in English and literature. Based on an interview, UIN Yogyakarta needs to provide more teaching staff with educational background in Indonesian language to cater provide better service for BIPA students (M. Zamhari, personal communication, 2019). Different circumstance happens at IAIN Tulung-agung since BIPA is covered in courses in the TBI Study Program. This is to say that the teachers have backgrounds from Indonesian language and literature and English language and literature.

In Egypt, the BIPA program features the lecturers that are divided into two categories: local BIPA teachers and the teaching delegation from PPSDK (Pusat Pengembangan Strategi Diplomasi Kebahasaaan/Language Diplomacy and Strategy Development Centre). Local BIPA teachers are language teachers who have passed a selection held by the Indonesian Embassy in Cairo's Education and Culture Attaché. They have the latest master's education or at least have been registered as students of a master program at one of the universities in Egypt, and have attended training or workshops related to BIPA teaching either held in Indonesia or held in Egypt. Second, the teaching delegation from PPSDK. They are BIPA teacher who are plotted at several BIPA course institutions or at universities in Indonesia, and has passed a selection held by PPSDK in the Indonesian language internationalization program to recruit Indonesian language teachers at Indonesian language course institutions in Egypt. They will come and serve in Egypt within a maximum period of four months in one assignment period. In one year, these teachers will be sent in two stages of departure in two semesters.

Given the circumstance of BIPA teachers both in Indonesian PTKI and Egypt, BIPA teachers at PTKI institutions only partially meet the requirements of SNP standards for BIPA at PTKI institutions. The language teachers for BIPA at PTKI have language education background and most of them possess Indonesian language or literature background. IAIN Surakarta can be considered to be the most prepared institution to implement the BIPA 
program because the teaching staff is in accordance with the Decree of the Director General of Islamic Education number 6244 of 2019. The language teacher should have the first level academic qualification with a background in Indonesian/Indonesian Literature education. Meanwhile, in Egypt, BIPA teaching staff are better prepared to implement the BIPA program at Al-Azhar University, because teaching staff are strictly selected to maintain university prestige.

\section{BIPA students}

BIPA students at PTKI institutions in Indonesia come from various countries and speak their mother tongue according to the language of the country. For more details, it can be seen in the table 2 .

Table 2. Country of Origin of BIPA PTKI Students

\begin{tabular}{lll}
\hline No. & PTKI & Country of origin \\
\hline 1. & IAIN Tulungagung & Thailand \\
\hline 2. & UIN Syarif Hidayatullah Jakarta & No international student \\
\hline 3. & $\begin{array}{l}\text { UIN Maulana Malik Ibrahim } \\
\text { Malang }\end{array}$ & $\begin{array}{l}\text { Malaysia, Sudan, Libya, Mesir, Irak, Yaman, } \\
\text { Somalia, Saudi Arabia, China, Thailand, } \\
\text { Kamboja, Rusia }\end{array}$ \\
\hline 4. & UIN Yogyakarta & $\begin{array}{l}\text { Malaysia, Thailand, Afganistan, Maroko, } \\
\text { Aljazair, Rusia }\end{array}$ \\
\hline 5. & IAIN Surakarta & Thailand, Filipina \\
\hline
\end{tabular}

Based on the data in table 2, UIN Malang has BIPA students that are heterogeneous, because they come from various countries. IAIN Tulungagung has BIPA students that are homogeneous, because all of the students come from Thailand and its number is the highest among the five PTKI institutions. Participants from BIPA UIN Jakarta and UIN Malang do not only come from foreign students studying at the local PTKI, but also from professional backgrounds outside of campus. Meanwhile, IAIN Surakarta, IAIN Tulungagung, and UIN Yogyakarta consist of BIPA students that study at the local campus. From this point of view, UIN Jakarta and UIN Malang can be considered to be more prepared than other PTKI institutions.

In Egypt, BIPA program is intended for Egyptians and other international communities who are interested in getting to know Indonesia more closely through learning Indonesian language and culture. BIPA program students in Egypt come from all walks of life. They belong to different professions, ranging from students, employees, businessmen, journalists, tour guides, and workers in other fields. Based on the results of observations, this study found that the objectives of BIPA program in Egypt can be categorized in terms of their participants into four types namely: (1) elementary school age children can take BIPA 1 to BIPA 2 courses, (2) junior high school age children can attend BIPA 1 to BIPA 4 courses, (3) high school age teenagers and above can attend BIPA 1 to BIPA 7 courses, and (4) adult participants with various professional backgrounds can attend BIPA 1 to BIPA 7 courses.

In Egypt, BIPA has opened learning opportunities for participants from outside the campus with various professional backgrounds. Given this situation, BIPA in Egypt can be compared with BIPA held by UIN Jakarta and UIN Malang.

\section{Evaluation of BIPA Program}

At PTKI institutions in Indonesia, the assessment on language learners' competence at BIPA program is carried out by officials from BIPA apprentices. The program evaluation includes: class attendance, assignments, practice, discussions, group presentations, and final exams for learning. The assessment used in the learning process includes all tasks given to 
students including mastery of aspects of knowledge, skills, and attitudes or behavior. The assessment criteria refers to PAP (Penilaian Acuan Patokan/Norm Criteria Reference). The description and interpretation of the assessment can be seen in table 3 .

Table 3. Range of Assessment for BIPA Program at PTKI Institutions

\begin{tabular}{ccl}
\hline Band Score & Quality & Explanation \\
\hline $80-100$ & A & Very Good \\
\hline $70-79$ & B & Good \\
\hline $60-69$ & C & Enough \\
\hline $50-59$ & D & Less \\
\hline $0-49$ & E & Very Less \\
\hline
\end{tabular}

Based on the results of interviews with BIPA teachers at IAIN Surakarta, this study found that the overall evaluation activity was carried out at the end of the semester. It was performed by carrying out written and oral examinations for language learners. The results of the evaluation is written on the documents of a certificate stating that the participants of BIPA program had passed and graduated the program (Ulfiana, personal communication, December 3, 2019)

In Egypt, the evaluation on language learner's competence taking BIPA program is also administered. Some important aspects are taken into consideration when evaluating language learners.

1. Evaluation of BIPA students is administered at the end of learning activity. It takes two test formats: a formative and summative competency test. They are designed to meet the need of the learner's level. The competency test consists of listening, speaking, reading and writing skills. They are delivered in a packaged in several written exams; middle exam, program final exam, and one oral exam. The exam is carried out at every level of BIPA. The assessment criteria consisted of (daily activity score x $20 \%$, program mid-test score $\mathrm{x}$ $25 \%$, program final exam score $x 35 \%$, oral exam score $\mathrm{x} 20 \%$ ). The criteria of accumulative assessments used can be seen in the table below.

Table 4. Range of Assessment for BIPA Program Egypt

\begin{tabular}{ccl}
\hline Band Score & Quality & Explanation \\
\hline $80-100$ & A & Very Good \\
\hline $70-79$ & B & Good \\
\hline $60-69$ & C & Enough \\
\hline $50-59$ & D & Less \\
\hline
\end{tabular}

2. UKBI (Uji kemahiran Bahasa Indonesia/Indonesian language skill test) is carried out at the end of the course of BIPA program. Students are measured in terms of their competence and understanding of Indonesian language skills.

Based on an interview, this study found that Students taking BIPA program in Egypt will receive the results of their assessment. They will be notified when they passed the assessment at each level. one level of learning is carried out according to the learning plan. A certificate is given to students who have passed the assessment on BIPA courses and training at each level (Suryadi, personal communication, December 6, 2019).

Given the above evaluation which is administered by both BIPA program at PTKI institutions in Indonesia and in Egypt, this study found that they have shared similarities in the evaluation coverage, evaluation criteria, and evaluation objectives. The implementation of the evaluation is well managed by BIPA program in Indonesia and in Egypt. The evaluation has been designed to measure language learners' ability in accomplishing BIPA program and 
demonstrating language skill competence. The evaluation is carried out covering the process and the end of the activity; the exam includes formative and summative. This kind of evaluation also applies in a number of educational institutions. There are several formats of evaluation. One of them is daily evaluation which is done through a process of learning activities, such as questions and answers. Other formats are carried out weekly, and at the end of the semester. Other format applies practical exams to demonstrate language learner's performance in using the language.

Based on the above findings, there are several points to discuss. The Language Development and Development Agency has also developed a core curriculum in BIPA teaching and helped develop curricula in BIPA teaching institutions (Arumdyahsari et al., 2016). Teaching materials are an important component in the implementation of BIPA teaching. Therefore, the Language Development and Development Agency has prepared teaching materials, both main and supporting teaching materials, and has distributed these teaching materials to institutions that provide BIPA teaching. The tutorial model of BIPA learning is basically BIPA learning which has its own characteristics. However, regardless of the specifications of the learning manifestation, it cannot be separated from the essential things that should exist in BIPA learning in general. The essential things meant include, among others, the components, principles, and basic rules of BIPA learning. Therefore, for the sake of discussing the BIPA tutorial model, it is necessary to have an adequate understanding of these essential matters. Furthermore, this understanding can be used to see and correctly position the perspective of the tutorial model from various aspects, especially in terms of its application feasibility.

BIPA learning can be viewed as a system consisting of a number of supporting components, namely instructional and non-instructional components. The relationship and functional interaction between these components will create a teaching and learning process and learning outcomes (Winkel, 1987). In BIPA learning, the existence and role of learners is a prominent component. It can be said, this learner component is also what significantly differentiates between BIPA learning and other Indonesian language learning. The figure of BIPA learners as foreign speakers of Indonesian has certain characteristics, especially seen in (1) personal characteristics, (2) background of origin, (3) fields, (4) knowledge/abilities, (5) interests, (6) learning objectives, (7) learning strategies, and (8) learning time. The existence and condition of these learners will have implications for their role and relationship with other instructional components in the embodiment of BIPA learning. Furthermore, the characteristics of learners are also materials that must be considered as influential variables and determine in BIPA learning (Stern, 1987).

BIPA learning has a specific target, which is to form learners who have the ability to speak language naturally. In a broader sense, this fairness is related to other things, including culture which is always inherent in the substance of language. Therefore, in addition to the problems of the personal characteristics of learners, cultural issues are also involved in the creation of BIPA learning. Moreover, if BIPA learning is held in Indonesia, then considerations from a socio-cultural perspective will become increasingly important. It is said so, because these considerations will at the same time become a vehicle and need for learners to communicate directly and factually (Widodo, 2001).

BIPA learning as a program, of course, has a clear base as seen in the basic principles of learning in general. Likewise, as a form of language learning, it should also be based on the conceptual rules of foreign language learning which are the basis of the approach. The conceptual rules in question are mainly sourced from language theory and language learning theory (Spolsky, 1980; Stern, 1987). Aspectually, BIPA learning specifications, among others, appear in (1) learning objectives, (2) learning objectives, (3) material structure, (4) method 
selection, (5) resource/media utilization, (6) learning activities, (7) ) learning evaluation, and (8) problematic learning. Considering that the manifestation of these aspects of learning is quite complex, a clear conceptual basis for BIPA learning is needed. Without a clear reference, it is possible that the direction of BIPA learning will be biased and have a negative effect on productivity.

The description of BIPA learning as stated above, shows that BIPA learning is a complex subject. Its complexity is not only seen in the instructional component, but also in its relationship with other factors in the embodiment of BIPA learning. To realize adequate BIPA learning, of course, it is necessary to consider these things carefully and thoroughly. In terms of organizational and management patterns, BIPA learning should (1) be able to develop learning motivation, and (2) be able to make it easy for learners to master Indonesian naturally. These targets must be mapped and realized in a specific and clear form or BIPA learning model. In terms of activities, basically BIPA learning is a process of modeling learning behavior that leads to generating and conditioning the motivation of learners in Indonesian. The essential thing that needs to get priority and special attention is how to develop learning in such a way that it can condition and make it easy for learners to want and be able to speak Indonesian naturally $(\mathrm{Hb}, 2017)$.

These efforts require a specific learning management system, especially with regard to learning mechanisms that are effective, accommodative, conducive, and oriented to the needs/interests of learners. This means that the planning and learning process should be developed systematically, thoroughly, and reached out to develop motivation and awareness of learners on clear learning targets. In addition, starting from the existence of language as a behavioral subsystem, it is also necessary to develop learning patterns that can create a learning mood towards accustomed Indonesian language in the form of factual experiences. In foreign language mastery, factual experience has a very important role, especially in the embodiment of input and achievement of output (Cook, 1994). The illustration of the BIPA learning pattern can be visualized as in the following figure.

\section{CONCLUSION}

BIPA program has contributed to the development of Islamic education at PTKI institutions in Indonesia and overseas. In Indonesia, there are five PTKIs institutions that carry out BIPA programs and each institution features different institutions, curricula, instructors, students. In Egypt, BIPA program has been administered by Al-Azhar University. The program aims to preach Islam in accordance with the mission of Al-Azhar University that is Islam with moderate and tolerant outlook. Indonesian language is widely used by the majority of Southeast Asian nations whose population majority is Muslim. Southeast Asian countries need scholars from al-Azhar who master local traditions and culture so that Indonesian becomes the second academic language at Al-Azhar University. BIPA management conducted by PTKI institutions and Al-Azhar university, Egypt in terms of institution, curriculum, language teachers, language learners, evaluation have applied islamic perspective (Aqeeda and Sharia) and Islamic values which are compatible with the regulation set by Direktur Jenderal Pendidikan Islam (Directorate General for Islamic Education) Number 6244 Year 2019. Referring to this regulation, both BIPA program at PTKI institutions and $\mathrm{Al}$-azhar university are considered ready and successful.

\section{BIBLIOGRAPHY}

Adryansyah. (2012). Babasa Indonesia bagi Penutur Asing (BIPA) —Profil BIPA Badan Pengembangan dan Pembinaan Bahasa. Tim BIPA BPPB. 
Arumdyahsari, S., Hs, W., \& Gatut, S. (2016). Pengembangan Bahan Ajar Bahasa Indonesia bagi Penutur Asing (BIPA) Tingkat Madya. Jumal Pendidikan: Teori, Penelitian, dan Pengembangan, 1(5), 828-834. https://doi.org/10.17977/jp.v1i5.6263

Binsahi, H., Chang, S., \& Bosua, R. (2020). Cross-Cultural Digital Information-Seeking Experiences: The Case of Saudi Arabian Female International Students. Journal of International Students, 10(4), 873. https://doi.org/10.32674/jis.v10i3.1573

Cintamulya, I. (2019). Analysis of students' Critical Thinking Skills with Reflective and Impulsive Cognitive Styles on Conservation and Environmental Knowledge Learning. Asia-Pacific Forum on Science Learning and Teaching, 20(1), 1-14.

Cook, V. (1994). Linguistic and Second Language Acquisition. London: The Macmilan Press Ltd.

Dewi, F. A. A., Mustiningsih, \& Habiburrahman, L. (2019). Implementation of Curriculum in Multicultural Communities of BIPA Universitas Negeri Malang, Indonesia. Proceedings of the 4th International Conference on Education and Management (COEMA 2019). Proceedings of the 4th International Conference on Education and Management (COEMA 2019), Malang, East Java, Indonesia. https://doi.org/10.2991/coema-19.2019.24

Haryati, G., Andayani, \& Anindyarini, A. (2019). Forms of Local Culture in Indonesian Language Teaching Books for Foreign Speakers (BIPA). International Journal of Research and Innovation in Social Science (IJRISS), III(VII), 151-159.

Hb, Z. (2017). Pembelajaran Bahasa Indonesia bagi Penutur Asing (BIPA) dan Model Pembelajaran Tutorial. Tarbiyah al-Awlad, 7(2), Article 2. https://ejournal.uinib.ac.id /jurnal/index.php/alawlad/article/view/429

Hertiki, H. (2018). Pengajaran dan Pembelajaran BIPA di Perguruan Tinggi Polandia. Jurnal Pendidikan Bahasa dan Sastra Indonesia, 6(2), 1-5.

Isnaniah, S. \& Islahuddin. (2020). Management of Indonesian Language Learning for Foreign Speakers (BIPA) at Islamic Religious Higher Education Institutions (PTKI) in Indonesia and Thailand. Jurnal Pendidikan Islam, 9(1), 1-27. https://doi.org/10.14421/jpi.2020.91.1-27

Jannah, R., \& Gusti Yanti, P. (2020). Pembelajaran Bahasa Indonesia bagi Penutur Asing Menggunakan Metode Darmawisata. Imajeri: Jurnal Pendidikan Bahasa dan Sastra Indonesia, 2(2), 182-189. https://doi.org/10.22236/imajeri.v2i2.5096

Kurniasih, D., \& Isnaniah, S. (2019). Penerapan Bahan Ajar Bahasa Indonesia bagi Penutur Asing (BIPA) "Sahabatku Indonesia" Tingkat Dasar di IAIN Surakarta. JBIPA: Jurnal Babasa Indonesia Bagi Penutur Asing, 1(2), 62-71. https://doi.org /10.26499/jbipa.v1i2.1793

Kusmiatun, A. (2016). Mengenal BIPA dan Pembelajarannya. K Media.

Lestyarini, B. (2012). Model Sintetik dan Analitik Berbasis Karakter Indonesia dalam Pembelajaran BIPA di Era Global. Seminar Internasional ASILE 2012 dan KIPBIPA VIII LTCUKSW, Salatiga.

Liliana, M. (2017). Bahasa Indonesia bagi Penutur Asing. Yayasan Pustaka Obor Indonesia.

Muhaimin, S., \& Prabowo, S. L. (2012). Manajemen Pendidikan. Kencana Prenada Media Group.

Putra, M. I. R. (2020). Media Pembelajaran Bahasa Indonesia Bagi Penutur Asing. Jurnal Education and Development, 8(2), 19.

Qomar, M. (2007). Manajemen Pendidikan Islam Strategi baru Pengelolaan Lembaga Pendidikan Islam. Jakarta: Erlangga.

Quinones, R. P. J., \& Marissa, L. M. (2020). Bahasa Indonesia Language Program Impact Analysis in the Polytechnic University of the Philippines Manila: A Basis for the Bahasa Indonesia's Inclusion in the ab English Language Studies' and ab Literary and Cultural Studies' Curriculum. JBIPA: Jurnal Bahasa Indonesia Bagi Penutur Asing, 2(1), 11-21. https://doi.org/10.26499/jbipa.v2i1.2401 
Rafiek, M. (2014). Bahasa Indonesia sebagai Bahasa Persatuan Indonesia: Kenyataan, Tantangan, dan Peluang bagi Pengembangan dan Pembinaan Bahasa. Paper, Presented on Seminar Kebahasaan in Hari Sumpah Pemuda. Balai Bahasa Provinsi Kalimantan Selatan.

Rahman, A., Warsah, I., \& Murfi, A. (2019). Islamic Education System in Singapore: Current Issues and Challenges. Jurnal Pendidikan Islam, 8(2), 197-222. https://doi.org/10.14421/jpi.2019.82.197-222

Saddhono, K. (2012). Kajian Sosiolinguistik Pemakaian Bahasa Mahasiswa Asing dalam Pembelajaran Bahasa Indonesia untuk Penutur Asing (BIPA) di Universitas Sebelas Maret. Kajian Linguistike dan Sastra, 24(2), 176-186. https:/ / doi.org/10.23917/kls.v24i2.96

Soegihartono, A. (2012). Pembakuan Pembelajaran Bahasa Indonesia bagi Penutur Asing sebagai Sarana Pengenalan Budaya Indonesia. International Conference on Indonesian Studies, Depok.

Stern, H. H. (1987). Fundamental Concepts of Language Teaching. Oxford University Press.

Supriyanto, E. (2004). Inovasi Pendidikan. Surakarta: Muhammadiyah University Press.

Suyitno, I. (2008). Norma Pedagogis dan Analisis Kebutuhan Belajar dalam Pembelajaran Bahasa Indonesia untuk Penutur Asing (BIPA). Diksi: Jurnal Ilmiah Bahasa, Sastra Dan Pengajarannya, 15(1), 111-119. https://doi.org/10.21831/diksi.v15i1.6561

Thoyib, M. (2008). Internasionalisasi Pendidikan dan Strategi Pengembangan Mutu Perguruan Tinggi Agama Islam di Indonesia: Sketsa Edukatif Manajemen Mutu. Jurnal Pendidikan Islam El-Tarbawi, 1(2), 215-234. https://doi.org/10.20885/tarbawi.vol1.iss2.art5

Widodo, H. S. (2001). Pembelajaran Babasa Indonesia bagi Penutur Asing Model Tutorial. Malang: CIS-BIPA Universitas Malang.

Winkel, W. S. (1987). Psikologi Pengajaran. Jakarta: Gramedia.

Zulfahmi, H. B. (2016). Pembelajaran Bahasa Indonesia bagi Penutur Asing (BIPA) dan Model Pembelajaran Tutorial Pembelajaran Bahasa Indonesia bagi Penutur Asing (BIPA) dan Model Pembelajaran Tutorial. Jurnal Tarbiyah Al-Awlad, VI(2), 600-609. 